\title{
Polyphenol Compounds of Mahkota Dewa (Phaleria macrocarpa [Scheff.] Boerl) Up-regulated Caspase-3 and Apoptosis Index in Balb/c Strain Mice
}

\author{
Indranila KS ${ }^{1}$, Theopilus W. Watuguly ${ }^{2}$, Lyle Craker ${ }^{3}$, and Judiono $\mathbf{J}^{4}$
}

${ }^{1}$ Department of Clinical Pathology, Faculty of Medicine, Diponegoro University, Semarang, Indonesia; ${ }^{2}$ Department of Biomedical, Medical Faculty of Pattimura University, Ambon, Indonesia; ${ }^{3}$ Medicinal Plant Program at the University of Massachusetts, Amherst, MA 01003, USA; ${ }^{4}$ Department of Nutrition, The Bandung Health Polytechnic, West Java, 40173, Indonesia

*Corresponding author: Indranila Kustarini Samsuria, $\mathrm{PhD}$, Department of Clinical Pathology, Faculty of Medicine, Diponegoro University, Semarang 50275, Indonesia

Submission date: January 18, 2016; Acceptance date: April 25, 2016; Publication date: April 27, 2016

\begin{abstract}
Background: Polyphenol compounds of Mahkota Dewa (Phaleria macrocarpa [Scheff.] Boerl (PMD) can potentially be used as anticancer treatment by scavanging radical molecules. The effect in vivo is still limited to Indonesia.
\end{abstract}

Purpose: This research was aimed to validate the activity of PMD in increasing caspase-3 expression and apoptosis in Balb/c mice, induced by Benzo(a)pyrene (BaP).

Methods: A post test control group was implemented and used by $40 \mathrm{Balb} / \mathrm{c}$ mice at the age of 1-2 weeks, with the body weight of 20-30 g. The tumor induction was administered to the mice using $\mathrm{BaP}$. The animals were randomized into two groups called the control group and the PMD treatment group, the latter of which was given a dosage of 50mg. Lung tumor growth was assessed through surgery at week 8, 17, and 26. The results of caspase-3 expression and apoptotic index from IHC-TUNEL staining were analyzed using Kruskal-Wallis, MannWhitney, One-way ANOVA, and Post hoc test LSD with significant levels of $p<\alpha(0,05)$. This research was approved by Ethical Clearance.

Results: Oral administration of 50mg PMD significantly increased caspase-3 expression and apoptotic index in the treatment group animals at weeks 8, 17, and 26. Carcinogenesis incidence in the control group were respectively found at $2,32 \pm 0,26$ and $3,93 \pm 0,46$ at weeks 8 and 26 , while those of the treatment group were $1,88 \pm 0,38$ and $0,88 \pm 0,22(\mathrm{p}=0,001)$. The apoptotic index in the control group was $0,00 \pm 0,00$ at 8 weeks and $0,92 \pm 0,22$ at 26 weeks, whereas the indexes of the treatment group were $1,12 \pm 0,71$ and $2,02 \pm 1,05(\mathrm{p}=0,001)$. In the control group, the caspase-3 expression at weeks 8 and 26 were $0,28 \pm 0,17$ and $0,56 \pm 0,16$, while those in the treatment group were $0,60 \pm 0,14$ at week 8 and 2,52 $\pm 0,33$ at week $26(p=0,001)$.

Conclusion: The treatment of PMD effectively induced cell apoptosis in the Balb/c mice via up- 
regulation of the caspase-3 expression, thereby increasing the apoptotic index. This shows that PMD has anticancer abilities to inhibit lung carcinogenesis in Balb/c mice.

Keywords: polyphenol, mahkota dewa (Phaleria macrocarpa [Scheff.] Boerl), cell proliferation, apoptotic index, Balb/c strain mice, Benzo(a)pyrene (BaP).

\section{INTRODUCTION}

As seen within this epidemiology study, lung cancer is the most threatening cancer type in the world when compared to prostate, breast and colorectal cancer [1]. The overall survival of lung cancer patients is $15 \%$ within 5 years. However, these statistics can be even worse when diagnosed at an advanced stage of this cancer [2]. Surgery and chemotherapy, alone or in combination with radiotherapy, are the therapeutic choices for lung cancer patients [3]. Unfortunately, at the advanced stages of lung cancer, these types of therapy are less effective in prolonging the survival rate in patients [4]. A study by Syahrudin E, et al (2005) reported that overall survival and therapeutic response in various chemotherapy modalities demonstrated similar results [5]. Similarly, Masuda N, et al (2000) revealed that in non-small cell lung cancer (NSCLC), chemotherapy resulted in a good response, whereas in small cell lung cancer (SCLC), the therapeutic response was dependent on the individual patient [6]. Consequently, current novel strategies to suppress lung cancer focus on preventive work.

Apoptosis is an integral molecular process, involving death receptor and mitochondrial pathway [7,8]. It employs receptor-ligand proteins (i.e. FasL/CD95L with Fas/CD95) [9], regulator proteins (i.e Bcl-2, Bcl-xL, Bax, Apaf-1, PUMA, Noxa, Smac-Diablo) [10, 11], and several proteases that play a crucial role in the apoptotic process, including caspase 9, 8, 7, 6 and $3[12,13]$. The apoptotic mitochondrial pathway isinitiated by the activation of the tumor suppressor protein p53, an essential regulator for cellular stress [2]. The p53 activation will be accompanied by up-regulation of pro-apoptosis proteins (Bax, Bad, Bid, PUMA, Apaf-1) and/or down-regulation of anti-apoptosis protein (Bcl-2, Bcl-xL) [14] as a response to DNA damage [15] which induces cytochrome $\mathrm{c}$ release from mitochondria [16]. The cytochrome c release will trigger caspase activation, thereby inducing the apoptotic process $[13,17]$. In contrast, the death receptor pathway is induced by the death receptor's activation on the cell surface, such as Tumor Necrosis Factor (TNF) and Fas ligand (FasL) [14]. Active FasL recruits intracellular Fasassociated death domain (FADD) to form a complex with procaspase- 8 [18, 19]. Procaspase-8 transactivation produces active caspase- 8 that directlycleaves procaspase- 3 into caspase- 3 . After subsequent activation, apoptosis will occur or induce more activation signal via Bid cleavage [20]. Moreover, according to Owen-Schaub LB, et al (2005), the importance of p53 is that it can induce activation in both the mitochondrial and death receptor pathways, thereby activating caspase-8 [21].

The caspase protein plays crucial roles in apoptosis signaling and execution [22]. Reduced caspase expression influences apoptosis process and disturbs cell proliferation [23]. Caspase-3 was found in low grades of malignancy, which can be an indicator for a good prognosis with lung carcinoma [24, 25]. However, high caspase-3 expression is related to a worse prognosis in resected NSCLC. 
Mahkota dewa (MD) (Phaleria macrocarpa [Scheff.] Boerl is one of the Indonesian traditional herbal plants reported to have anti-cancer activity. Its activity is hypothesized to be related to polyphenol compounds. Based on phtochemistry analisis of MD extract, polyphenol was one of the abundant compounds found in MD. However, the activity of polyphenol compounds from MD (PMD) to modulate lung cancer cell apoptosis in vivo has not been explored. Thus, the current study aims to investigate the activity of PMD in the in vivo lung cancer model.

\section{MATERIAL AND METHODS}

Carcinogenic model [26,27]: Every Balb/c mouse at the age of 24-48 hours was subcutaneously injected at sub-scapula region with $0.02 \mathrm{ml}$ suspension containing $0.2 \mathrm{mg}$ in $1 \%$ Benzo (A) Pyrene $(\mathrm{BaP})$ solution (single dose). A carcinogen was used during an hour period after emulsification. Then, mice were raised together with their mother, supplemented with water and food ad libitum. At the average time of 4 weeks, male and female mice were then separated and divided into two groups.

The first group was the carcinogenic control, which were not given the oral PMD, but injected only with BaP up to the $26^{\text {th }}$ week. In contrast, the second group was the PMD treatment group was given PMD orally by dosage of $50 \mathrm{mg} / \mathrm{mouse} /$ day starting from the $5^{\text {th }}$ week of BaP injections until the $26^{\text {th }}$ week. At weeks 8, 17, and 26, parameters for both groups were determined. Each group consisted of 30 animals, and 15 of them were sacrificed at each time point for histopathology and immunohistochemistry analysis.

Experimental design: Treatment of PMD began at week 5 after a BaP injection with the dosage of $50 \mathrm{mg}$ in each mouse, every day, and continuously up to the $26^{\text {th }}$ week. This research was approved by Ethical Clearance. Animals were determined by the following the guidelines from the Ethic Commission,Komisi Etik Penelitian Kesehatan (KEPK) Faculty of Medicine, Diponegoro University dan Dr. Kariadi Hospital, Semarang (No. Reg: 38/EC/FK/RSDK/2010).

Histopathology evaluation of the lung [27]: Histopathology evaluation was conducted using five lobus of the lung. Each lobus was washed using phosphate buffered saline (PBS) and placed on in blotting paper to remove remaining blood. The lung tissues were fixed in $10 \%$ normal formalin buffer for 24 hours in dehydrated and graded ethanol concentration, washed using xylene, and finally put in paraffin. The five lung lobus were cut, put on a slide and stained. Four $\mu \mathrm{m}$ serial region was used for hematoxylin-eosin (HE) staining, microscopic evaluation under light microscope, histopathology evaluation, AgNORs expression analysis, and apoptotic index (AI).

Briefly, HE staining was completed by putting the tissue section on a slide, soaked in xylol for 5 minutes; xylol II for 5 minutes; washed with graded alcohol for 3x 2 minutes, aquadest for 2 minutes; soaked in HE Lillie-Mayer for 5 minutes; washed in flowing water for 2 minutes, $0.4 \%$ acidic alcohol for $3 \mathrm{x}$, flowing water for 2 minutes, saturated Lithium carbonate for $3 \mathrm{x}$, flowing water for 2 minutes, $50 \%$ alcohol for 3x2 minutes, $70 \%$ alcohol, eosin, $70 \%$ alcohol 3x, carbon xylol, xylol 3x, xylol for 20 minutes, Canadian balsam; and at the end, cover with glass slide.

Immunohistochemistry: Immunohistochemistry staining was completed from lung tissue section according to protocol by Mohan KPVC, and et al. [28,29]. The tissue section of the slide 
was fixed using formalin for 20 minutes. After this, it was washed with Phosphate-buffered saline (PBS), incubated at $-20^{\circ} \mathrm{C}$ for 5 minutes and followed by acetone for 3-5 minutes, and then washed again using PBS. Prior to the blocking step, $\mathrm{H}_{2} \mathrm{O}_{2}$ was applied at $5^{\mathrm{O}} \mathrm{C}$ for 15 minutes. Non-specific antibody binding was blocked using normal serum for 10 minutes. The Caspase-3 expression in the tissue was detected by monoclonal antibodies. Incubation using primary antibodies was conducted for an hour and secondary antibodies for 30 minutes. To visualize the protein expression in tissue, peroxidase was applied for 30 seconds and diamino benzidine (DAB) was added for 3-5 minutes. Tissue section was counterstained using Mayer Hematoxylin Solution for 4 minutes, washed in alcohol and xylol, and then sealed using EZ mount.

The expression of caspase-3 in the lung tissue was observed using a light microscope connected to a direct screen (Mitsubishi), with 400x magnification from five different fields. The brown color of the cell's cytoplasm indicated the positive expression of the caspase- 3 protein, which came from the specific binding of monoclonal antibodies labeled horseradish with Caspase-3 proteins expressed in the cytoplasm. Addition of DAB substrate will react with horseradish and give brown color. In contrast, cells did not express caspase-3 protein will colored purple. Scoring was given to cells with positive brown staining in 100 counted cells.

Apoptosis detection: The apoptotic index was calculated from the number of cells undergoing apoptosis. Apoptotic cells are characterized by condensed and fragmented nuclei which are labeled using TUNEL and colored brown. Positive brown staining from the tumor tissue section is counted in apercentage of the apoptotic cells. Observation and counting of apoptotic cells come from five different fields, using a light microscope with 400x magnification.

Statistical analysis: The results from the cell proliferation and the apoptotic index were presented on a ratio scale. Descriptive analysis was presented using mean, median, mode, and standard deviation. From the histogram and plot, the normal data and data that is normal not are determined. Data analysis includes the Kruskal-Wallis test followed by the Mann-Whitney test. For the apoptotic index assessment, one-way ANOVA was used and followed by Post Hoc Test LSD (Least Square Difference). All statistical analysis was completed using SPSS vers. 19 by significance $\mathrm{p}<0,05$.

\section{RESULTS}

Evaluation of Caspase-3 expression using IHC: The higher apoptosis incidence in cells, the higher the p53 expression, which influences the ratio between Bax and Bcl-2 that induces caspase-3 expression. The effect of PMD on the caspase-3 expression was evaluated by histopathology observation from immunohistochemistry staining. The up-regulation of caspase-3 expression was observed in the PMD treatment group. As shown in the figure below (Figure 1), the cells stained positive in the bronchiolar region and were less in the PMD treatment group compared to the carcinogen control group. Quantitative analysis of casapase- 3 expression revealed that the expression in carcinogen control at weeks $8^{\prime} 17$, and 26 was $0,28 \pm 0,17,0,20 \pm$ 0,14 , and $0,56 \pm 0,16$, respectively. While in the PMD treatment group, caspase- 3 expression was higher in each analysis by weeks $8^{\prime} 17$, and 26 and was $0,60 \pm 0,14,0,96 \pm 0,16$, and 2,52 \pm 0,33 , respectively. These results were summarized in a boxplot graph (Figure 2). 

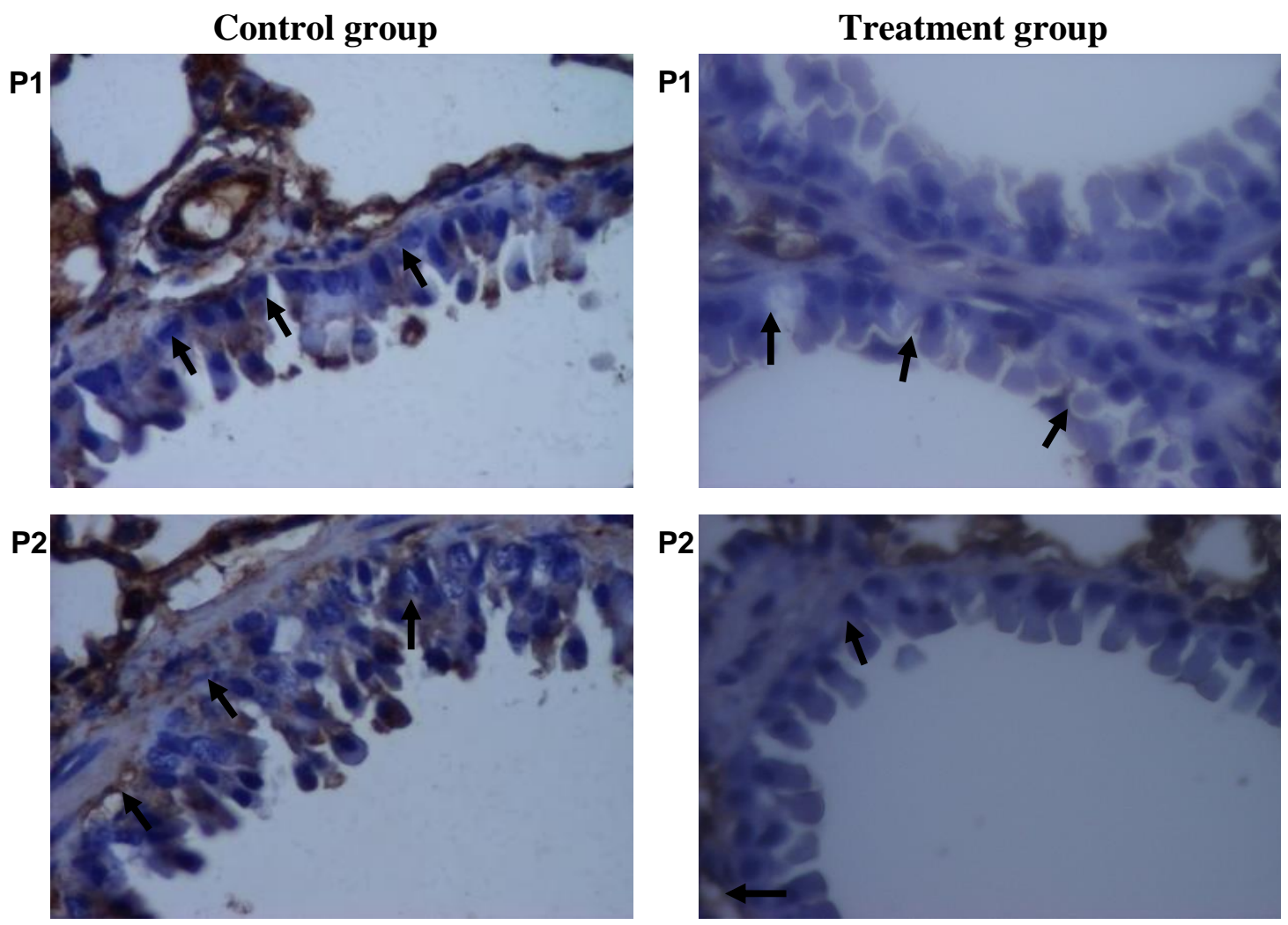

Figure 1. Localisation of caspase-3 expression in bronchioles cell in control and PMD treatment groups stained using immunohistochemistry.

The PMD treatment induced the caspase- 3 expression at the bronchial epithelium as shown by brown color in cytoplasm. Observation was done under 400x magnification. ( $\mathrm{P} 1=$ observation in pretest, and $\mathrm{P} 2=$ observation in post test)

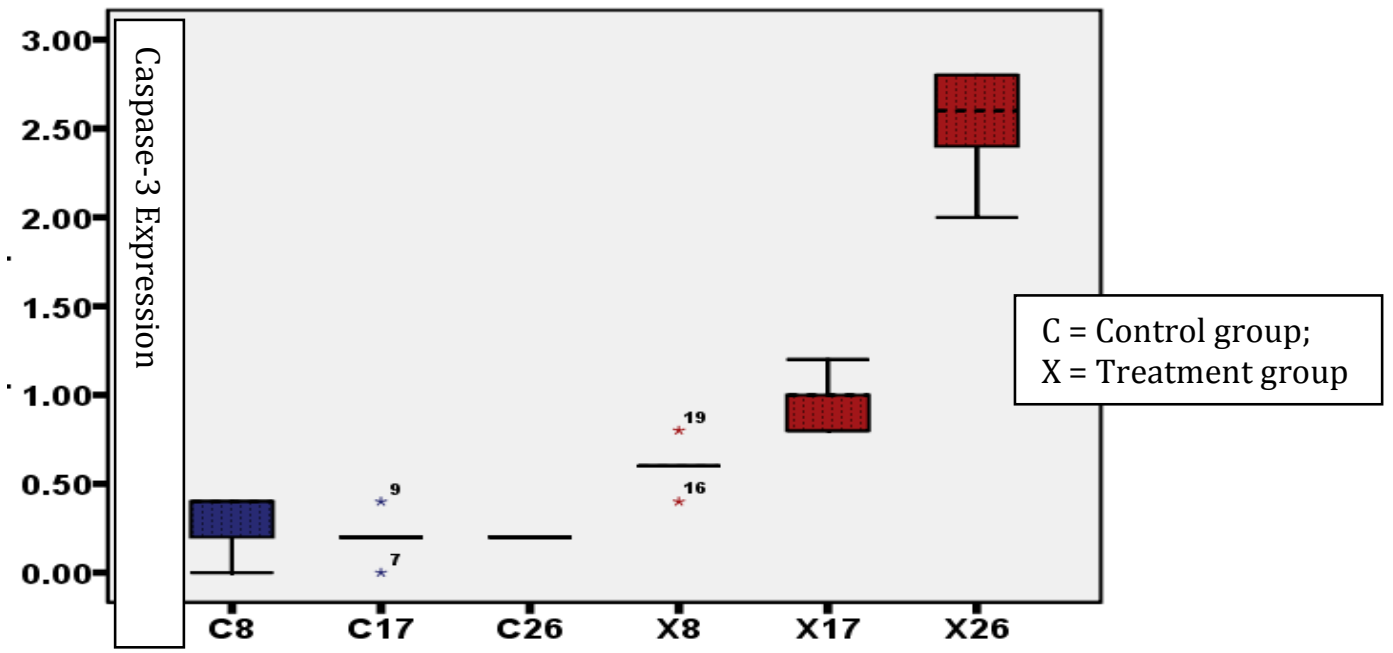

Figure 2. Boxplot graph of the PMD effect on caspase-3 expression in the control and PMD treatment groups from Balb/c mice induced by BP.

(* represents outlayers among the animals being treated) Statistical analysis was done using the Kruskal-Wallis test, which resulted in significant increase $(\mathrm{p}=0,001)$ of caspase-3 expression after PMD treatment during lung carcinogenesis. Moreover, the Mann-Whitney test was used to test significant differences between groups. The 
outcome exhibited that the increased caspase-3 expression at weeks 8, 17, and 26 in PMD treatment group was significantly different when compared to the control group, with significant value control-treatment of $\mathrm{p}=0,016$, $\mathrm{p}=0,008$, and $\mathrm{p}=0,008$, respectively.

Apoptotic Index: The TUNEL assay was performed to determine the apoptotic cells with high specificity. The apoptotic cells could be counted out of every 100 cells. The apoptotic index was then calculated from an average of this count from five different fields.

In our study, apoptosis induction was observed in bronchial epithelium cells in PMD treated mice compared to the control group (Figure 3). In line, the apoptotic index would increase due to the higher apoptotic cell number in this group (Figure 4). The apoptotic index at 8 weeks was $0,00 \pm 0,00$ in the control group, while in PMD treatment group was $1,12 \pm 0,71$. During carcinogenesis, the apoptotic index in the PME treatment group was increasing, that was 2,28 \pm 0,83 and $3,80 \pm 0,83$ at weeks 17 and 26 , respectively.
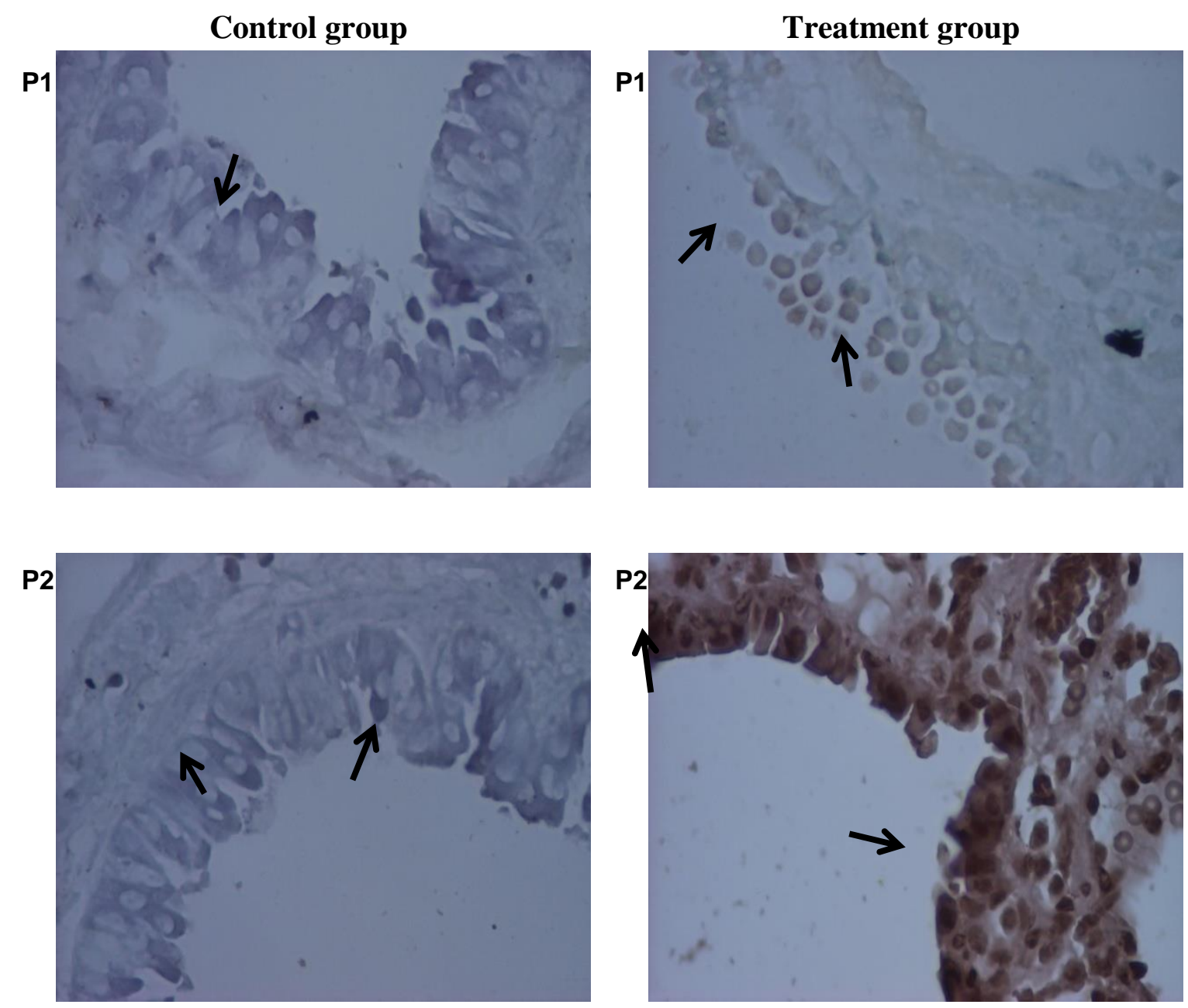

Figure 3. Apoptotic bodies were exhibited using TUNEL staining and brown coloring in the bronchial epithelium cells. Observation was done under 400x magnification. 


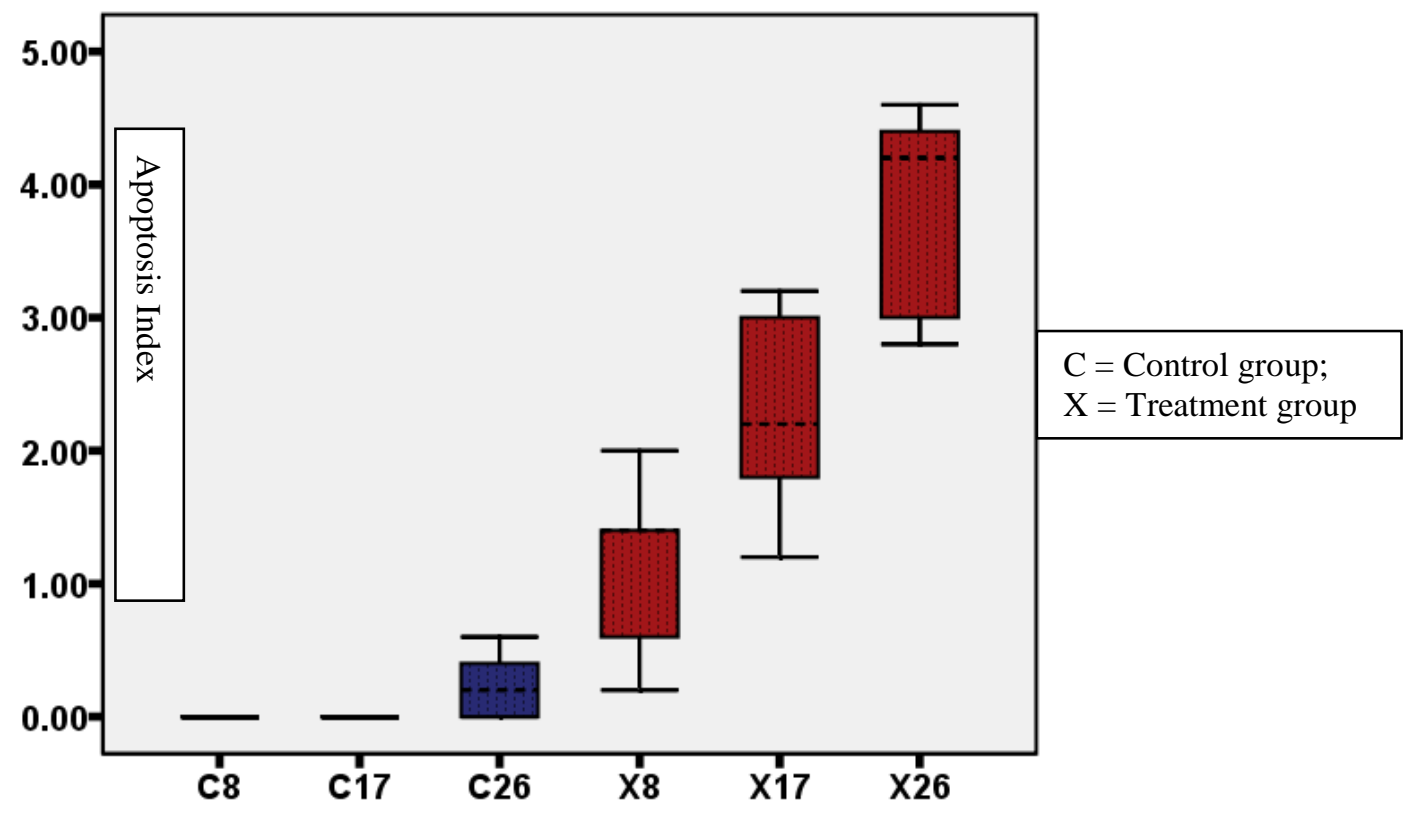

Figure 4. Boxplot graph of the PMD effect on the apoptotic index. The PMD treatment increased the apoptotic index in bronchioles region during lung carcinogenesis in Balb/c mice induced by BP.

Statistical analysis of apoptotic index resulted in normal distribution of the data and a similar variant. Thus, further analysis using one-way ANOVA followed by post hoc test LSD exhibited significant increase of the apoptotic index in the PMD treatment group compared to control carcinogenesis $(\mathrm{p}=0,001)$ at weeks 8,17 , and 26 . As a result, it was revealed that the increase of the apoptotic index during PMD treatment was significantly different compared to the control group with significant levels of control-PMD treatment of $(p=0,005),(p=0,001)$, $(\mathrm{p}=0,001)$ at weeks 817 , and 26 respectively.

\section{DISCUSSION}

Our study used mice separated into two groups. The first group was the carcinogenic control group, which was not given the oral PMD but was only injected with BaP up to the $26^{\text {th }}$ week. On the other hand, the second group was the PMD treatment group, which was given PMD orally by dosage of $50 \mathrm{mg} / \mathrm{mouse} /$ day starting from the $5^{\text {th }}$ week of BaP injection until the $26^{\text {th }}$ week. At weeks 8, 17, and 26, parameters for both groups were determined. Tumorigenesis is a multistep progress of genetic mutations/alterations, which is divided in 3 stages. First, the cell's DNA regulates various enzymes. Secondly, there is an over-expression of enzymes involved in the synthesis and regulation of DNA nucleoties and differentiation processes. During the last stage, the cell proliferation is uncontrolled and undergoes metastasis.

The study of polyphenol compounds as anti-oxidants demonstrated that these compounds were able to induce cell survival, in contrast to pro-oxidant polyphenols, which induced apoptosis, cell death, and inhibited cell proliferation [30, 31]. Moreover, polyphenols are able to disrupt carcinogenesis through several mechanisms. In particular, during early carcinogenesis, polyphenols have the ability to counteract the oxidative pressure caused by a tumor [32, 33]. Consequently, by modulating the oxidative pressure in cancer cells, signal tranduction, 
transcription factors that are redox-sensitive, and gene expression related to apoptosis and proliferation would be disturbed, leading to carcinogenesis inhibition [34, 35].

Apoptosis is the key to cell death via DNA damage that will eliminate unhealthy cells [36, 37]. The decline of apoptotic cells in cancer play an essential role during each stage of carcinogenesis, due to the accumulation of defective DNA [38]. The disruption of apoptosis may indicate the early carcinogenesis occurence and failure of tumor cell to undergo apoptosis, which will lead to its maliganant form and chemotherapeutic resistant [39, 40]. In this phase, an apoptotic inducer can be used as an anti-carcinogenic agent to reverse the apoptotic incidence. In our study, PMD treatment was shown to enhance apoptotic incidence during each stage of lung carcinogenesis in Balb/c mice induced by BP at weeks 8, 17, and 26.

The apoptotic incidence is characterized by morphological change, including chromatin condensation, nucleus fragmentation, membrane blebbing, and cell shrinkage [19]. At the molecular level, apoptosis is described as a complex network that employ $>100$ proteins that actively contribute to signal tranduction, zymogen cascade, and the execution process. One of the proteins of our interest is the caspase-3 protein, an active form of procaspase-3, which is important at the execution phase of apoptosis. Caspase- 3 is activated after the assembly of aptosomal [41]. Caspase-3 and caspase-7 are substrate for CASP9 that is activated by proteolytic due to cleavage and binding of tetrameric enzymes.

In our study, oral PMD treatment in mice clearly increased caspase-3 expression compared to the control group. This result was confirmed by the statistical analysis $p=0,001$ that was below 0,05. As a result, our hypothesis which stated that PMD compounds induce apoptosis via upregulation of caspase-3 expression, was demonstrated. Furthermore, PMD compounds were able to induce Bax and Bcl-2, so cytochrome-c would be release from mitochondria and activate caspase-3, as shown in Figure 5. The figure below indicates that PMD compounds induce apoptosis through two mechanisms which are via death receptor by activating caspase- 8 and via mitochondrial pathway by inducing caspase-9. Both pathways will lead to activation of caspase3 and apoptosis induction.

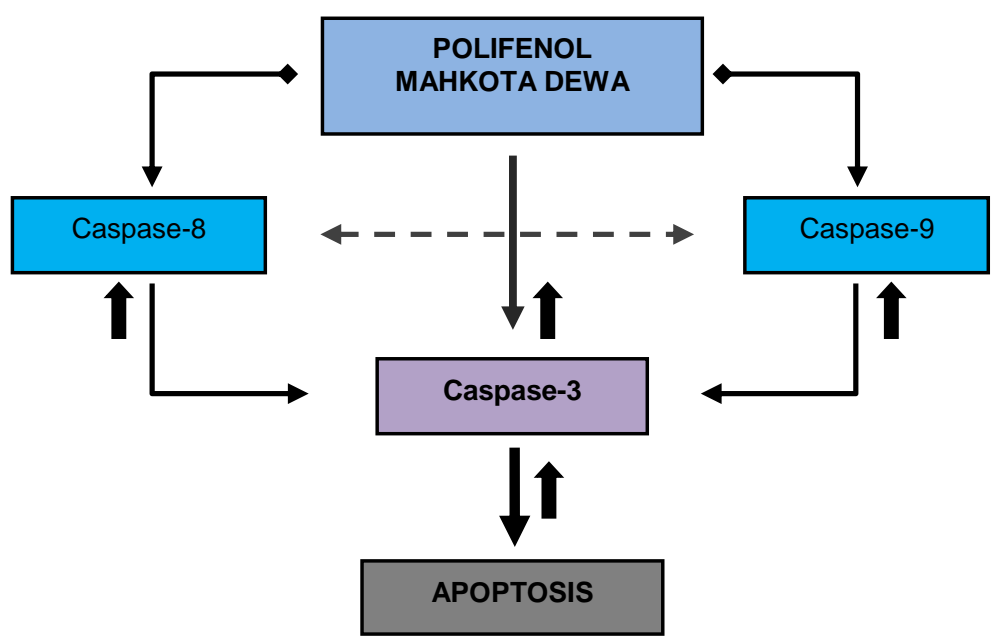

Figure 5.The mechanisms of PMDin inducing apoptosis were via death receptor pathway and mitochondrial pathway. 
The results of our study were in line with several previous reports. In a study by Mohan KVPC et al., apoptosis incidence was induced via the increased expression of caspase- 3 that came from combination bLF and P-B in HBP carcinogenesis [28]. According to Benerjee S et al., polyphenol compounds from black tea increased caspase-3 expression in the treatment group compared to thecontrol group [42]. Moreover, in evaluation of anti-proliferative, anti-angiogenic, and apoptotic induction from black tea polyphenols, they were also able to enhance caspase-3 expression [29]. Other polyphenols from black tea, such as EGCG and theaflavin, were shown to induce apoptosis during skin carcinogenesis induced by BenzO(A) Pyrene (BAP) [43]. The results above exhibited that PMD might be responsible in apoptosis induction through caspase-3 modulation.

Up to the present, studies report that the use of caspase as a marker for lung cancer was limited. Theoritically, in SLCCin vivo study, caspase-3 expression was directly correlated with apoptosis that influenced overall survival [44]. Furthermore, the level of caspase-3 expression corresponded to lymph node metastasis, in which low caspase-3 expression led to poor prognosis [24]. As a result, it was suggested that the downstream pathway of caspase-3 may contribute to apoptosis resistance [45].

The cells undergoing apoptosis will have condensed chromatin, shrinkage of cells, and smaller nuclei. Membrane blebbing together with nucleus fragmentation will produce a clear apoptotic body that can be observed microscopically using histology staining, H\&E staining, or TUNEL (Terminal deoxynucleotidyl transferase-mediated dUTP-biotin nick and labeling) immunohistochemistry assay. TUNEL assay that has a high specificity, combines molecular and immunohistochemistry detection to visualize apoptotic cells. The binding of fragmented DNA with degoxigenin aided by TdT enzyme (terminal deoxynucleotide transferase) marks molecular reaction, while immunohistochemistry reaction is marked by immunological reaction between antigen-antibody and chemical reaction between enzyme-substrate. The TUNEL assay uses TdTFragEl for detection in which TdT binds to 3-OH of fragmented DNA, then labeled biotin and unlabeled deoxy-nucleotide is added. Biotynilated nucleotide will be detected from its binding to the streptavidine-horseradish peroxidase. The addition of diaminobezidine substrate will give colour to the labeled sample which indicates the fragmented DNA [46]. By using TUNEL assay, we observed morphological changes in cells that underwent apoptosis, including membrane blebbing, cell shrinkage, an increase in permeability and decline in mithochondrial membrane potential. Therefore, it was proved that oral PMD treatment does induce apoptosis in mice of PMD treatment group.

The semi quantitative analysis of our study also showed the higher apoptotic index in the PMD treatment group compared to the control group in mice. This result was confirmed by statistical analysis using significant levels of $p=0,001$. Because the significant value was below 0,05 , our hypothesis stated that PMD compounds increase apoptotic index was accepted. Our result was in accordance with a previous study that reported the ability of EGCG in raising the apoptotic index in human epidermis carcinoma cell, A431 [47]. In the human colon adenocarcinoma cell, HT29, apoptotic induction was observed after EGCG treatment [48]. In line, in in vivo study EGCG and theaflavin treatment exhibited similar results, suggesting that both polyphenols could inhibit cell proliferation and induce apoptosis leading to carcinogenesis disturbance [27]. 


\section{CONCLUSION}

The polyphenol compounds from mahkota dewa (PMD) were able to induce cell apoptosis through up-regulation of the caspase-3 expression, thereby increasing the apoptotic index in Balb/c mice induced by benzo(a)pyrene (BaP).

Competing interests: The authors declare that they have no competing interests with anyone or with any organizations.

Authors' Contributions: All authors contributed to this study. Indranila KS designed and conducted the study, performed the data analysis including the statistical analysis, and drafted the manuscript. Theopilus Watuguly initiated the study design and conducted the study. Lyle Craker supervised and co-designed the entire study, and also co-revised and edited the manuscript in its entirety. Judiono conducted the data analysis, including the statistical analysis, and drafted the manuscript.

Anknowledgement: The views expressed herein are those of the individual authors, and do not necessarily reflect those of any funding institution. We express our gratitude to honourable Professor Dr. Chayono, Professsor Edi Dharmana who has given her support and ideas on the implementation of this study. Integrated Biomolecular Laboratory The Bandung Health Polytechnic, MOH R.I.

\section{REFERENCES}

1. Robert T Greenlee, Hill-Harmon MB, Murray T, Thun M. The new World Health Organization classification of lung tumours. Eur Respir J 2001; 18: 1059-68.

2. R.H.J Breuer, Postmus PE, Smit EF. Molecular pathology of non-small-cell lung cancer. Respiration 2005; 72: 313-330.

3. Caputi M, Russo G, Esposito V, Mancini A, Giordano A. Role of cell-cycle regulators in lung cancer. Journal of Cellular Physiology 2005; 205: 319-327.

4. Joan H. Schiller., David Harrington., Chandra P. Belani., Corey Langer., Alan Sandler., James Krook., Junming Zhu., David H. Johnson. Comparison of Four Chemotherapy Regimens for Advanced Non-Small-Cell Lung Cancer. The N Engl J Med 2002; 346:92-98 January 10, 2002.

5. Syahruddin E. Mekanisme non-P-glycoprotein multidrug resistence (non P-gP MDR) dan factor yang terlibat pada resisten sel kanker paru. J Respir. Indo. 2005, Vol. 23, No. 2, hal. 93-98.

6. Masuda N, Fukuoka M, Fujita A, Kurita T, Tsuchiya S, Nagao K. A. Fase II trial of combination of CPT-11 and cisplatin for advanced non-small-cell lung cancer. Br J. Cancer 2000; 78: 251-6.

7. Kaufmann SH, Vaux DL. Alterations in the apoptosic machinery and their potential role in anticancer drug resistance. Oncogene 2003; 22: 7414-30.

8. Gupta S. Molecular signaling in death receptor and mitochondria pathway of apoptosis (review). Int. J. Oncol 2003; 22: 15-20. 
9. Ashkenazi A, Dixit VM. Apoptosis control by death and decoy receptors. Curr Opin Cell Biol 1998; 11: 255-260.

10. Wu X, Deng Y. Bax and BH3-domain-only proteins in p53-mediated apoptosis. Front Biosci 2002; 7: 151-6.

11. Kuwana T, Newmeyer DD. Bcl-2-family proteins and the role of mitochondria in apoptosis. Curr Opin Cell Biol 2003; 15: 691-699.

12. Fun TJ, Han LH, Cong RS, Liang J. Caspase family proteases and apoptosis. Acta Biochi et Biophy Sinica 2005; 37(11): 719-27.

13. Sareen D, Ginkel van PR, Takach J. C, Mohiuddin A, Darjatmoko SR, Albert DM and Polans AS. Mitochondria as the primary target of resveratrol-induced apoptosis in human retinoblastoma cells. Investigative Ophthalmology \& Visual Science 2006; 47 (9): 37083716.

14. Hanahan D and Weinberg R. A. The hallmark of cancer. Cell 2000; 100: 57-70.

15. Karen H. Vousden., Xin Lu. Live or let die: the cell's response to p53. Nature Reviews Cancer 2, 594-604 (August 2002)

16. Fisher DE. Apoptosis in the cancer therapy: crossing the threshold. Cell 2004; 78: 539-542.

17. Zimmermann KC, Bonzon C, Green DR. The machinery of programmed cell death. Pharmacol. Ther. 2001; 92: 57-70.

18. Pop C, Timmer J, Sperandio S, Salvesen GS. The apoptosome activates caspase-9 by dimerization. Mol Cell 2006; 22: 269-275.

19. Viktorsson K, Lewensohn R. Apoptotic signaling pathways in lung cancer. Journal of Thoracic Oncology 2007; 2(3): 175-179.

20. Garrido C, Galluzzi L, Brunet M, Puig PE, Didelot C, Kroemer G. Mechanisms of cytochrome c release from mitochondria. Cell Death Different 2006; 13: 1423-1433.

21. Owen-Schaub L. B, Zhang W, Cusack J. C, Angelo L. S, Santee S. M, Fujiwara T, Roth J. A, Deisseroth A. B, Zhang W-W, Kruzel E, Radinsky R. Wild-type p53 and a temperature sensitive mutant induce FasrAPO-1 expression. Mol Cell Biol 1995; 15: 3032-3040.

22. Zhivotovsky B, Orrenius S. Carcinogenesis and apoptosis: paradigms and paradoxes: review. Carcinogenesis 2006; 27 (10): 1939-1945.

23. Fujikawa K, Shiraki K, Sugimoto K, Ito T, Yamanaka T, Takase K, Nakano T. Reduced expression of ICE/caspase1 and CPP32/caspase3 in human hepatocellular carcinoma. Anticancer Res. 2000; 20: 1927-1932.

24. Volm M, Mattern J, Koomagi R. Inverse correlation between apoptotic (Fas ligand, caspase-3) and angiogenic factors (VEGF, microvessel density) in squamous cell lung carcinomas. Anticancer Res 1999; 19: 1669-71.

25. Koomagi R, Volm M. Relationship between the expression of caspase-3 and the clinical outcome of patients with non-small cell lung cancer. Anticancer Res. 2000; 20: 493-496.

26. Taik-Koo Y, Sung-Ho K, Yun-Sil L. Trial of a new medium-term model using benzo(a)pyrene induced lung tumor in newborn mice. Anticancer Res. 1995; 15: 839-846.

27. Banerjee S, Manna S, Saha P, Panda CKr, Das S. Black tea polyphenols suppress cell proliferation and induce apoptosis during benzo(a)pyrene-induced lung carsinogenesis. European Journal of Cancer Prevention, 2005; 14: 215-221. 
28. Mohan KPVC, Devaraj H, Prathiba D, Hara Y, Nagini S. Antiproliferative and apoptosis inducing effect of lactoferrin and black tea polyphenol combination on hamster buccal pouch carcinogenesis. Bioch. et Biophy. Acta 2006; 1760(10): 1536-44.

29. Letchoumy PV, Mohan KVPC, Prathiba D, Hara Y, Siddavaram N. Comparative evaluation of antiproliferative, antiangiogenic and apoptosis inducing potential of black tea polyphenols in the hamster buccal pouch carcinogenesis model. Journal of Carcinogenesis 2007; 6(19): 1-13.

30. Rice-Evans CA, Miller NJ, Bolwell PG, Bramley PM, Pridham JB. The relative antioxidant activities of plant-derived polyphenolic flavonoids. Free Radic Res 2005; 22: 375-83.

31. Giovannini C, Scazzocchio B, Vari R, Santangelo C, Archivio D' M and Masella R. Apoptosis in cancer and artherosclerosis: poliphenol activities. Ann Ist Suoer Sabita 2007; 43(4): 406-416.

32. Yao LH, Jiang YM, Shi J, Tomas-Barberan FA, Datta N, Singanungsong R, Chen SS. Flavonoids I food and their health benefits. Plant Foods Hum. Nutr. 2004: 59: 113-22.

33. Porrini M, Riso P, Brusamolino A, Berti C, Guarnieri S, Visioli F. Daily intake of a formulated tomato drink affects carotenoid plasma and lymphocyte concentrations and improves cellular antioxidant protection. Br J. Nutr. 2005; 93: 93-99.

34. Sang S, Hou Z, Lambert JD, Yang CS. Redox properties of tea polyphenols and related biological activities. Antioxid Redox Signal 2005; 7: 1740-14.

35. Rahman I, Biswas SK, Kirkham PA. Regulation of inflammation and redox signaling by dietary polyphenols. Biochem Pharmacol 2006; 72: 1439-52.

36. Williams GT, Smith CA. Molecular regulation of apoptosis: genetic control of cell death. Cell 1993; 74: 777-779.

37. Kerr JF, Winterford CM, Harmon BV. Apoptosis. Its significance in cancerand cancer therapy. Cancer 1994; 73: 2013-2026.

38. Bedi A, Pasricha PJ, Akhtar AJ. Inhibition of apoptosis during development of colorectal cancer. Cancer Res 1995; 55: 1811-1816.

39. Vermeulen K, Bockstaele Van DR, Berneman ZN. Apoptosis: mechanism and relevance in cancer. Ann. Hematol. 2005; 84: 627-639.

40. Khan N, Afaq F, Mukhtar H. Apoptosis by dietary factors: the suicide solution for delaying cancer growth. Carcinogenesis 2007; 28(2): 233-239.

41. Yuan CQ, Ding ZH. Structure and function of caspases. Guowai Yixue Fenzi Shengwuxue Fence 2002; 24: 146-151.

42. Banerjee S, Manna S, Mukherjee S, Pal Debalina, Panda CKr, Das S. Black tea polyphenols restrict benzo(a)pyrene-induced mouse lung cancer progression through inhibition of Cox-2 and induction of caspase-3 expression. Asian Pacific J Cancer Prev 2006; 7: 661-666.

43. Das S, Benerjee S, Saha P. The models for assessment of chemopreventive agents: Single organ models. Asian Pac. J. Cancer Prev. 2004; 5: 431-6.

44. Tormanen-Napankangas U, Soini Y, Kahlos K, Kinnula V, Paakko P. Expression of caspase-3, -6 and -8 and their relation to apoptosis in non-small cell carcinoma. Int $\mathbf{J}$ Cancer 2001; 93: 192-8. 
45. Fennell DA. Caspase regulation in non-small cell lung cancer and its potential for therapeutic exploitation. Clinical Cancer Research 2005; 11: 2097-2105.

46. Kelly KJ, Sandoval RM, Dunn KW, Molitoris BA, Dagher PC. A novel method to determine specificity and sensitivity of the TUNEL reaction in the quantitation of apoptosis. Am. J. Physiol Cell Physiol 2003; 284: C1309-C1318.

47. Ahmad N, Adhami VM, Afaq F, Feyes DK, Mukhtar H. Resveratrol causes WAF-1/p21mediated G1-phase arrest of cell cycle and induction of apoptosis in human epidermoid carcinoma A431 cells. Clin Cancer Res 2001; 7:1466-473.

48. Chen C, Shen G, Hebbar V, Hu R, Owuor ED, Kong AN. Epigallocatechin-3-gallateinduced stress signals in HT-29 human colon adenocarcinoma cells. Carcinogenesis 2003; 24: $1369-78$. 